\title{
FREEZING INFLUENCES, THE EXPOSURE OF IgG GLYCANS IN SERA FROM MULTIPLE SCLEROSIS PATIENTS
}

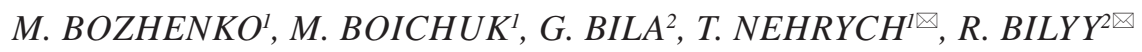 \\ ${ }^{1}$ Department of Neurology, Danylo Halytsky Lviv National Medical University, Lviv, Ukraine; \\ ${ }^{2}$ Department of Histology, Cytology and Embryology, Danylo Halytsky \\ Lviv National Medical University, Lviv, Ukraine; \\ 凶e-mail: r.bilyy@gmail.com; tnehrych@gmail.com
}

Received: 08 January 2020; Accepted: 27 March 2020

$N$-glycan residues attached to Asn297 of the immunoglobulin IgG molecule are responsible for changing its structural conformation and are used as markers of many inflammatory diseases. Freezing stabilizes protein structure, while recent solution NMR data showed greatly altered IgG glycan mobility at different temperatures. The aim of the current work was to investigate whether freezing sera samples from multiple sclerosis (MS) patients and normal healthy donors (NHD) influences exposure of IgG glycans. The developed lectin immunosorbent assay was used to evaluate exposure of native IgG glycans with fucose-binding AAL lectin and sialic acid-binding SNA lectin. Sera samples were divided and either immediately frozen at $-20{ }^{\circ} \mathrm{C}$ or stored at $4{ }^{\circ} \mathrm{C}$. Lectin exposure was compared between $5 \mathrm{MS}$ patient groups $(n=75)$ vs NHD $(n=23)$ and in paired samples with and without freezing. A significant increase in the exposure of fucose residues on IgG glycans in MS patients, compared to NHD, was observed. This increase was only observed if sera were frozen before analysis. The exposure of sialic acid was decreased in MS vs NHD samples after freezing sera samples. The exposure of core fucose residues and terminal sialic residues differed significantly in paired sera samples after freezing. Combined parameters of fucose and sialic acid exposure on native IgG glycans using frozen sera samples serve as a discriminative marker between MS and NHD. For AAL exposure, the discrimination of MS was characterized by AUROC of 0.906, sensitivity of 76.7\% and specificity of $59.0 \%(P<0.0001)$.

Ke y wo rds: IgG, glycosylation, freezing, inflammation, multiple sclerosis.

\section{Introduction}

Glycosylation of $\operatorname{IgG}$ (both native and artificially produced pharmaceutical monoclonal formulations [most are IgG]) has become an intensely growing "hot topic" in biomedical and pharmaceutical sciences [1], with studies of IgG glycans used to discriminate clinical conditions [2] and identify their roles in specific neurological conditions [3]. N-glycan residues attached to Asn297 of the IgG molecule are responsible for changing its structural conformation and subsequently the affinity towards pro- and anti-inflammatory receptors on effector cells [4]. Glycans undergo modification in specific pathologies and are used as markers of many inflammatory and autoimmune disorders, e.g., IgG autoantibodies in SLE lack sialic acids, as reviewed in detail [5].
Induced antigen exposure [6], or rheumatoid arthritis [7] are accompanied by increased fucose exposure on IgG N-glycan. Primarily due to successful reports, by merely altering the glycan residue of an antibody its proinflammatory potential can be lessened or even turned into anti-inflammatory potential. It is the native glycan configuration that determines the recognition of the Fc region of IgG by cellular receptors and modulates the immune response [5], making it different to study with denaturating techniques like mass spectrometry or western blotting. Data from of solution nuclear magnetic resonance (NMR) spectroscopy demonstrated the glycan residues in the IgG molecule are highly mobile [8] with the ability to move, be bound by ligand and mimic other glycan residues [9]. 
While involved in a multi-center study of native IgG glycans during autoimmune conditions, we realized that the type of sample storage and transportation greatly influences the exposure of native $\mathrm{IgG}$ glycans. This finding was not surprising given that freezing and defrosting are well known to alter the conformation of complex proteins: "cryoglobulins" or improperly folded immunoglobulins of the IgM type precipitate in peripheral vessels upon their cooling; while solution NMR techniques showed altered IgG glycan motility upon cooling to $5{ }^{\circ} \mathrm{C}$ [8]. The $4{ }^{\circ} \mathrm{C}$ structure of glycosylated Fc was indistinguishable from aglycosylated Fc if detected with NMR, while IgG1 Fc N-glycan was demonstrated to stabilize the COE loop of IgG through intramolecular interactions between carbohydrate and amino acid residues and preorganize the FcgRIIIa binding, and likely the antibody-dependent cellular cytotoxicity (ADCC) of the IgG molecule [11]. In clinical practice sera samples are either analyzed "fresh" thereby omitting freezing, or are frozen for longer preservation to avoid degradation of specific components.

Despite the fact that multiple sclerosis (MS) is an autoimmune disorder related to the production of autoantibodies that target myelin sheaths of effector cells and cause a range of symptoms from pain to paralysis of extremities, no single reliable marker of the disease exists. In our previous reports, we demonstrated [10] that lectins can be used for discrimination of altered IgG in MS patients.

Here we studied a large cohort of well-characterized MS patients, a total of 75 persons with different types of treatment, disease severity and duration. We applied the lectin-immunosorbent assay to detect native IgG glycans with the aim to discriminate MS patients $(n=75)$ from normal healthy donors (NHD, $n=23$ ). Upon collection of samples, we separated sera into two portions, with one portion kept at $4{ }^{\circ} \mathrm{C}$, while the other was frozen at $-20^{\circ} \mathrm{C}$. Then both samples were analyzed in parallel to compare the exposure of native glycan conformations and evaluate their usefulness as markers for MS diagnostics.

\section{Methods}

Patient cohorts. All analyses of human material were performed in accordance with the institutional guidelines and with the approval of the Ethics Committees of Danylo Halytsky Lviv National Medical University (DH LNMU No.5/2017-02-23). The current study involved 75 samples from MS patients being treated at the Department of Neurology, Danylo
Halytsky Lviv National Medical University (Lviv, Ukraine) and diagnosed with multiple sclerosis. Informed written consent for blood withdrawal was obtained from each patient and NHD.

Discrimination of MS was done on the basis of the 2010 revision of the McDonald criteria [12]. For each patient, the disease severity based on the expanded disability status scale (EDSS) [13] was evaluated and the disease duration was recorded. The main clinical parameters of the study: disease duration, stage and severity, as well as age and sex of the participants are summarized in Fig. 1. MS patients of five groups based on distinct therapeutic approaches assigned by the physician were studied: 1) untreated (naïve) patients, and those treated with 2) interferon (IFN), 3) corticosteroids, 4) monoclonal antibodies or 5) other types of therapies (including glatiramer acetate, copaxone, teriflunomide). A group of 23 age- and sex-matched volunteer NHD (13 men, 10 women, average age $=38$ years, interquartile range $[\mathrm{IQR}]=7$ years) who had no neurological disorders, served as a control group.

Determination of total serum IgG. Blood samples from MS patients and NHDs were supplemented with 2-(ethylmercuriomercapto)benzoic acid sodium salt $(0.01 \%$ final concentration $)$ and split into two portions, with one portion stored at $4{ }^{\circ} \mathrm{C}$, and the other frozen at $-20^{\circ}$, with a freezing rate close to $1{ }^{\circ} \mathrm{C} / \mathrm{min}$. For determination of total serum IgG, immunosorbent NUNC maxisorp plates (Thermo Scientific, Waltham, USA) were coated with $50 \mu 1$ of a $2 \mu \mathrm{g} / \mathrm{ml}$ solution of AffiniPure F(ab') ${ }_{2}$ Fragment goat anti-human $\operatorname{IgG}(\mathrm{H}+\mathrm{L})$ (Jackson ImmunoResearch, Cambridgeshire, UK) in $100 \mathrm{mM}$ carbonate-bicarbonate buffer ( $\mathrm{pH}$ 9.6). All serum samples were diluted 1:1 000 in washing buffer and incubated at $37{ }^{\circ} \mathrm{C}$ for $1 \mathrm{~h}$, after that the plates were washed again. Goat anti-human IgG $(\mathrm{H}+\mathrm{L})$ - horseradish peroxidase (HRP) (Jackson ImmunoResearch) was diluted in washing buffer (1:15 000) and was added to the plates and incubated at room temperature for $1 \mathrm{~h}$. After the corresponding washings, the assay was developed with 3,3',5,5'-tetramethylbezidine (TMB) containing $\mathrm{H}_{2} \mathrm{O}_{2}$ as a substrate. The reaction was stopped with $50 \mu \mathrm{l} /$ well of $1 \mathrm{~N}$ sulfuric acid. The absorbance was read at $450 \mathrm{~nm}$ using a Perkin Elmer BioAssay reader HST700 (Waltham, USA). The level of IgG in sera samples was approximately equal in all studied sera samples, however, its values were measured in duplicate in two separate parallel analyses with the lectin-binding assay. The data 
were used for normalization of lectin exposure per IgG molecule.

Lectin-immunosorbent assay for native IgG glycan exposure (Lectin-ELISA). The previously developed lectin-ELISA [7] was used for sensing exposed glycan structures on native IgG molecules following the coating of the plates with anti-human $\operatorname{IgG~F}\left(\mathrm{ab}^{\prime}\right)_{2}$-fragment. For blocking, a special deglycosylated blocking buffer ( $3 \%$ gelatin, $0.1 \% \mathrm{CaCl}_{2}$, $0.1 \% \mathrm{MgCl}_{2}, 0.05 \%$ tween-20) was applied to the plates. Deglycosylation of gelatin was achieved with 1\% periodic acid (Merck, Kenilworth, USA) treatment for $24 \mathrm{~h}$ to remove interfering glycan structures. The $\mathrm{pH} 7.4$ was restored by dialysis against Tris-buffered saline containing $0.1 \% \mathrm{CaCl}_{2}, 0.1 \%$ $\mathrm{MgCl}_{2}$ (TBS-Ca-Mg). After incubation at $37^{\circ} \mathrm{C}$ for $2 \mathrm{~h}$ the plates were washed three times after every incubation step with TBS-Ca-Mg and 0.05\% tween-20. Sera from MS patients or from NHD were diluted 1:1000 in TBS-Ca-Mg-tween and incubated at $37^{\circ} \mathrm{C}$ for $2 \mathrm{~h}$. A saturated binding of native complexed IgG to the ELISA plates was accomplished. To detect exposure of the IgG complex associated glycan structures and exposure of sialic acid, we used the biotinlabeled lectins AAL from Aleuria aurantia lectin (specific to core $\alpha 1,6$-fucose residue of branched $\mathrm{N}$-glycans, final concentration $100 \mathrm{ng} / \mathrm{ml}$ ), and SNA from Sambucus nigra bark agglutinin (recombinant carbohydrate-binding fragment, specific to terminal a2,6-sialic acid bound galactose, final concentration $100 \mathrm{ng} / \mathrm{ml}$ ), respectively. The plates were incubated at room temperature for $1 \mathrm{~h}$ and then washed three times. In order to detect lectin binding, HRPstreptavidin (Jackson ImmunoResearch) was used as recommended by the manufacturer. After incubation for another hour at room temperature, the color reaction was induced and optical density was determined using the Perkin Elmer BioAssay reader HST700.

Statistical analysis. All ELISA testing was performed in duplicate using 2 technical replicates for each analysis (coefficient of variation [CV] always $<3 \%$ ). The data were normalized between plates and corrected for background signal of secondary antibodies, then the mean values were calculated and are shown on the graphs. For comparisons between two groups, the Mann-Whitney U-test for numerical variables was used. For comparisons of multiple groups vs NHD or the untreated group, the Dunn's multiple comparisons test was employed. Wilcoxon matched-pairs test was used to compare pair values of glycan exposure data before and after freezing conditions. A receiver operating characteristic (ROC) curve was generated. The area under the ROC (AUROC) was calculated to estimate the specificity, sensitivity and usefulness of the binding assays. All analyses were performed using Excel 2016 (Microsoft Corp., Redmond, WA, USA) and Prism 7.0 (GraphPad, San Diego, USA) software. A $P$-value of $\leq 0.05$ was considered statistically significant. Four levels of significance are depicted in the figures by asterisks: $* P<0.05 ; * * P<0.01 ; * * * P<0.001$; $* * * * P<0.0001$. Individuals with missing data were not included in the respective analyses.

\section{Results}

Patient cohorts. The cohort of MS used in the study was characterized by comparable numbers of men $(n=32)$ and women $(n=43)$. In most cases (54 patients), the disease duration was more than 5 years, thus it was the chronic type. Only 12 patients were sampled during the acute stage of disease, while 63 patients donated blood during routine checks at the remission stage. Disease severity was low (EDSS score $0 \div 3.5$ ) in 38 patients, moderate (EDSS score $4 \div 5.5$ ) in 19 patients and high (EDSS score $6 \div 9$ ) in 18 patients (Fig. 1). The group of studied patients included 17 untreated (first diagnosed), 15 treated with IFN $\beta-1 b, 12$ treated with monoclonal antibodies against hyper-activated lymphocytes (namely ocrelizumab), 12 treated with conventional anti-inflammatory drugs like corticosteroids (methylprednisolone), and 19 patients receiving other types of treatment (referred to as "other").

For all patients, the disease activity was estimated based on the EDSS criteria. Physicians chose therapy for the patients based on the best possible solution for each patient, usually by the following strategy: IFN was prescribed as first-line therapy with a long history of MS treatment, and methylprednisolone was prescribed during periods of disease aggravation. Monoclonal antibodies were used as second-line therapy when primary treatment was not effective and/or disease symptoms were severe.

Exposure of core fucose on $\operatorname{Ig} G$ molecules. Lectin-ELISA testing of the $\alpha 1,6$-fucosyl core residue (core fucose) of N-glycan of IgG immunoglobulins was performed using AAL lectin. The principle of the validated test $[3,7,14]$ is demonstrated in the insert of Fig. 2, A.

Localization of the detected glycan in the IgG molecule can be ascertained from Fig. 2, A and 

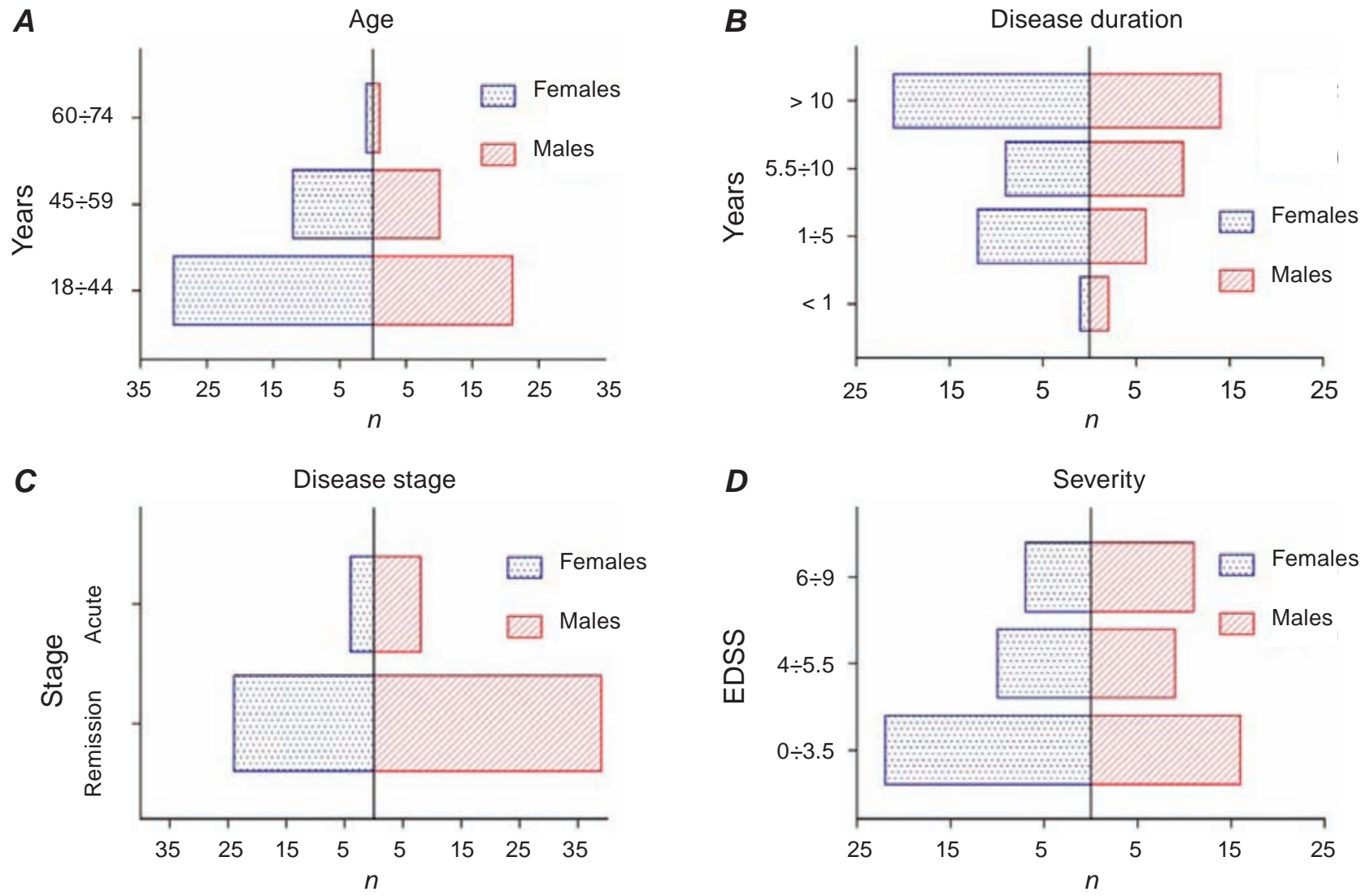

Fig. 1. Clinical characteristics of patients with multiple sclerosis. Population distribution based on (A) age, (B) disease duration, $(\boldsymbol{C})$ disease stage during sample analysis, and (D) disease severity based on the expanded disability status scale (EDSS)

Fig. 6. Exposure of core fucose residues to the sensing lectin was significantly stronger in all studied MS patient groups compared to NHD when samples were frozen before the analysis (Fig. 2, B). This difference in native glycan exposure was not observed when using unfrozen sera samples (Fig. 2, A). Thus with frozen conditions, the mean and median value of every tested group of MS patients was significantly higher than the NHD group, allowing discrimination of those samples. Fucose exposure in the untreated MS group was significantly lower than that of the IFN-treated group of patients.

Exposure of terminal sialic acids on IgG molecules. SNA lectin specific to terminal $\alpha 2,6$-sialic acids bound to galactose was used to evaluate exposure of terminal sialic acids on IgG molecules. We observed an increase in sialic acid exposure on IFN- and methylprednisolone-treated patients compared to the untreated cohort when using unfrozen sera samples (Fig. 3, A). The same tendency was observed when analyzing parallel samples after freezing (Fig. 3, B). In addition, terminal sialic acids were more accessible to lectin binding on the IgG samples from MS groups undergoing treatment with IFN, methylprednisolone, and other types of therapy when compared to NHD. Thus, freezing conditions change not only lectin accessibility to core fucose residues but also exposure of terminal sialic acid residues, which is in good accordance with recent solution NMR data regarding IgG glycan mobility [11].

Effect of freezing on glycan accessibility to lectins. The relative lectin binding ability in paired samples before and after freezing was calculated to evaluate the effect of freezing on glycan accessibility.

As can be seen from Fig. 4, $A$, freezing resulted in a highly significant increase $(P<0.001$ or $P<0.0001)$ in core fucose exposure in the groups of MS patients; this increase was of lower magnitude and lower significance $(P<0.01)$ for the group of NHD. At the same time for terminal sialic acids we observed the opposite effect since exposure of native 
A

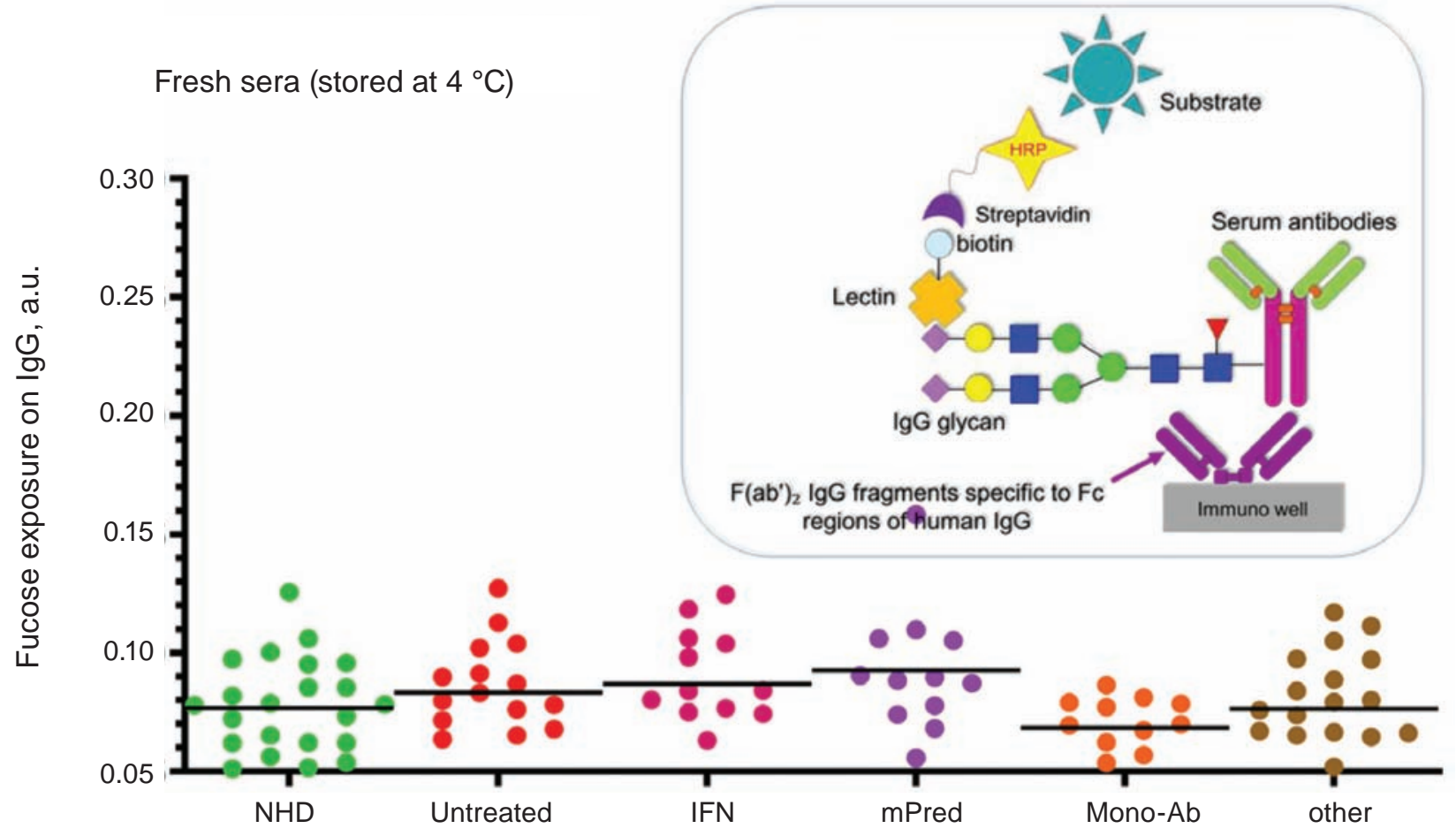

B

Frozen sera (stored $-20^{\circ} \mathrm{C},>30$ days)

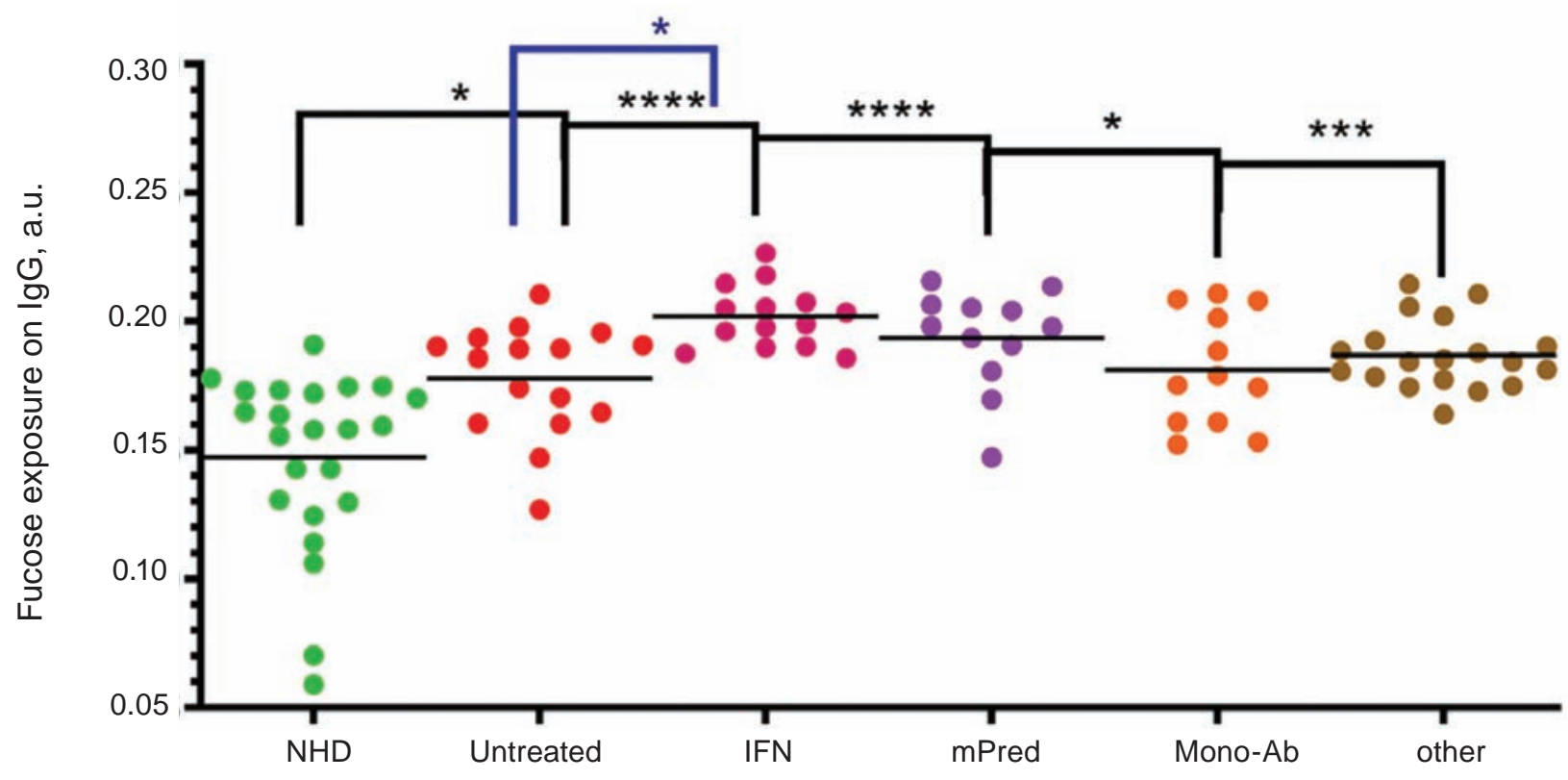

Fig. 2. Exposure of native core $\alpha 1$,6-fucosyl residue on N-glycan within IgG molecules. Data for (A) unfrozen, fresh samples and (B) samples after a cycle of freezing and defrosting. The principle of the used lectin-ELISA for the detection of glycan exposure on IgG is depicted in the insert. $* P<0.05 ; * * * P<0.001 ; * * * * P<0.0001$. $H R P$ - horseradish peroxidase, IFN - interferon, mPred-methylprednisolone, Mono-Ab - monoclonal antibodies, NHD - normal healthy donors 
A Fresh sera (stored at $4^{\circ} \mathrm{C}$ )

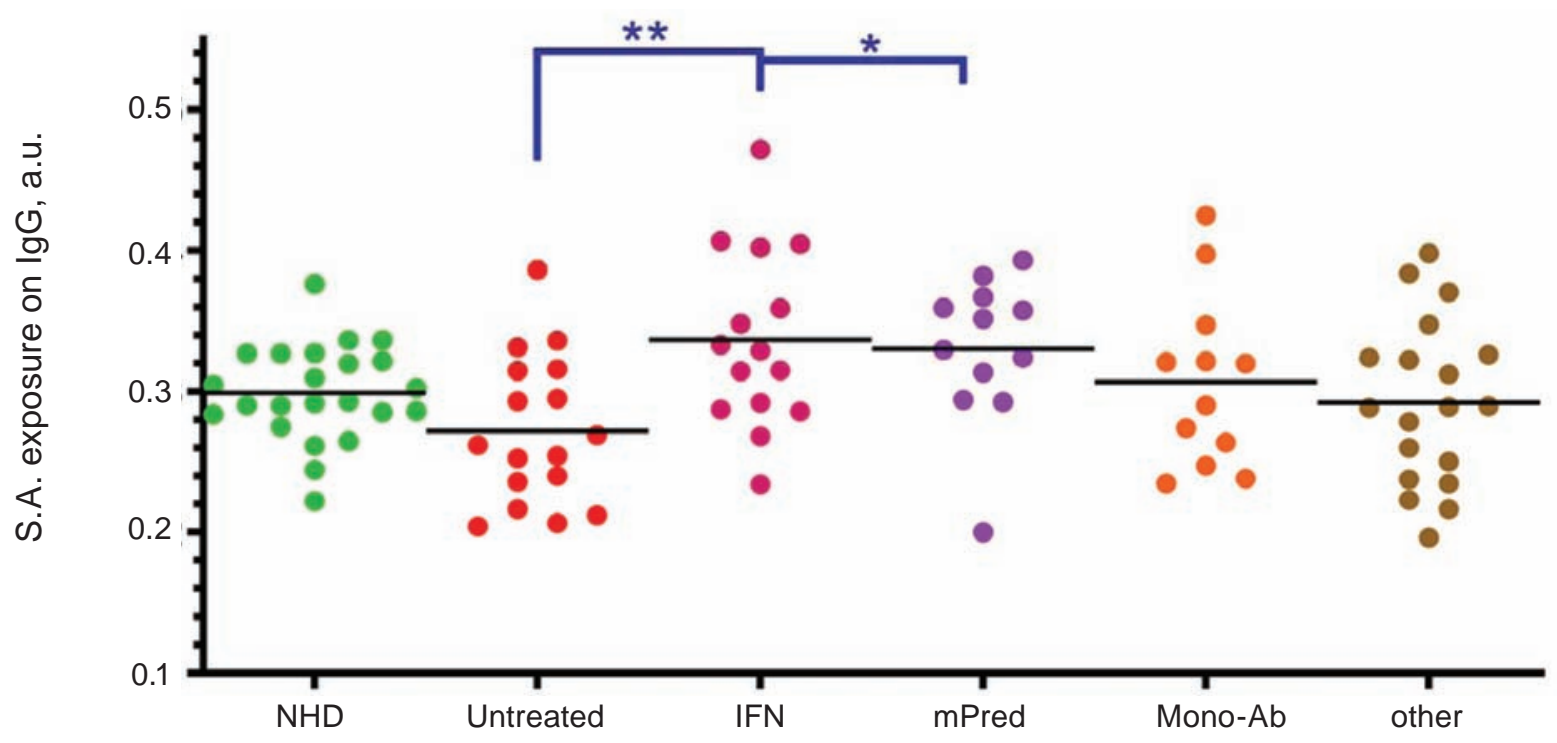

B Frozen sera (stored $-20^{\circ} \mathrm{C},>30$ days)

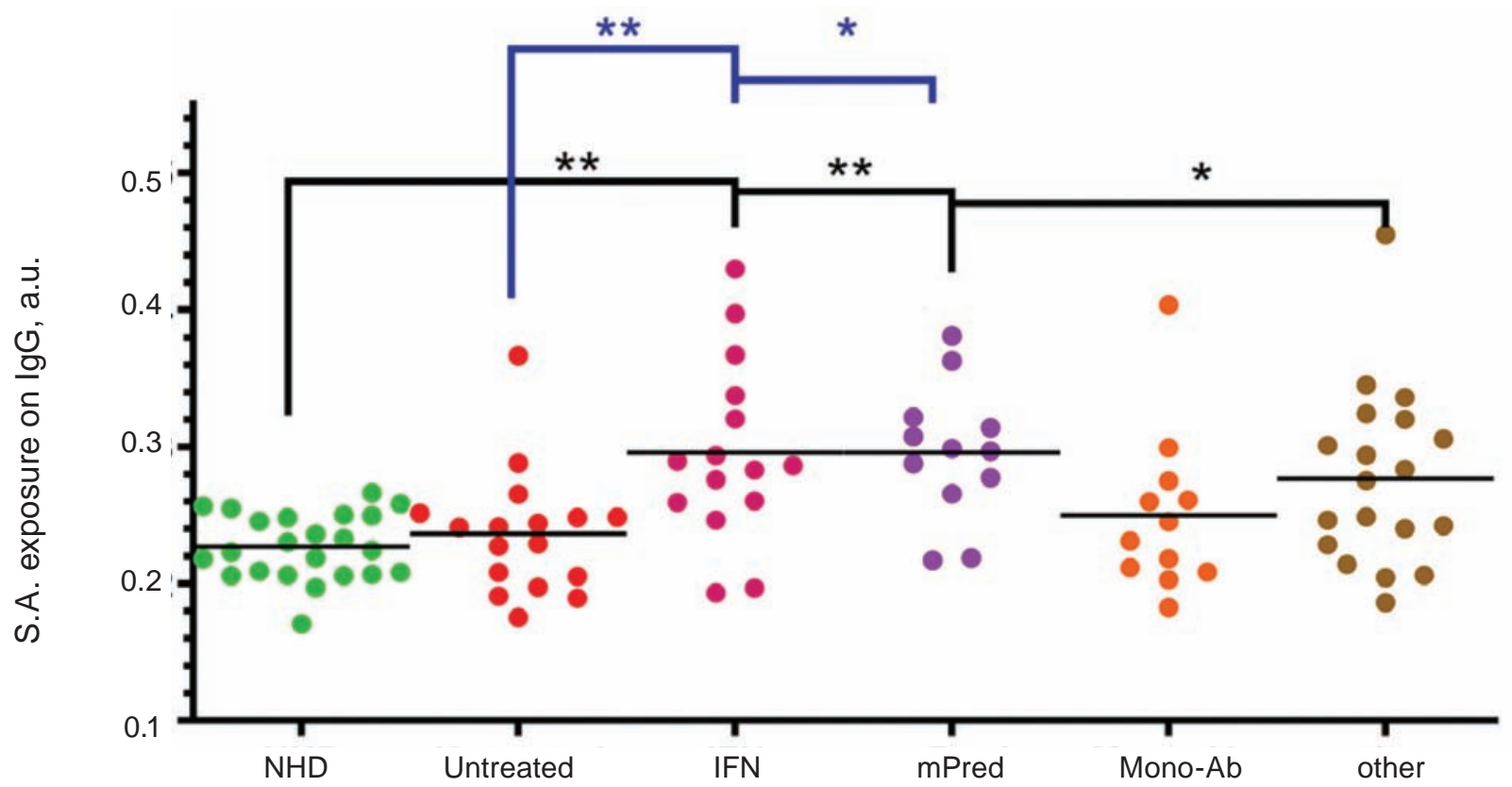

Fig. 3. Exposure of native terminal $\alpha 2,6$-sialic residues bound to galactose on $N$-glycan within IgG molecules. Data for (A) unfrozen, fresh samples and (B) samples after a cycle of freezing and defrosting. $* P<0.05$; $* * P<0.01$. IFN - interferon, mPred-methylprednisolone, Mono-Ab-monoclonal antibodies, NHD - normal healthy donors

glycans was decreased after freezing. This decrease was observed for MS patients undergoing therapy with IFN $(P<0.05)$, methylprednisolone $(P<0.05)$, monoclonal antibodies $(P<0.001)$, and untreated patients $(P<0.001)$ but was not significant for MS patients who received other types of therapies. The decrease of sialic acid exposure to SNA lectin was the strongest in the NHD group, this difference was also highly significant $(P<0.0001)$ (Fig. $4, B)$. Thus, freezing conditions caused unidirectional changes in the exposure of IgG immunoglobulin glycans, decreasing the accessibility of terminal sialic acids and 
$A$

Fucose exposure

Non-frozen

- Frozen

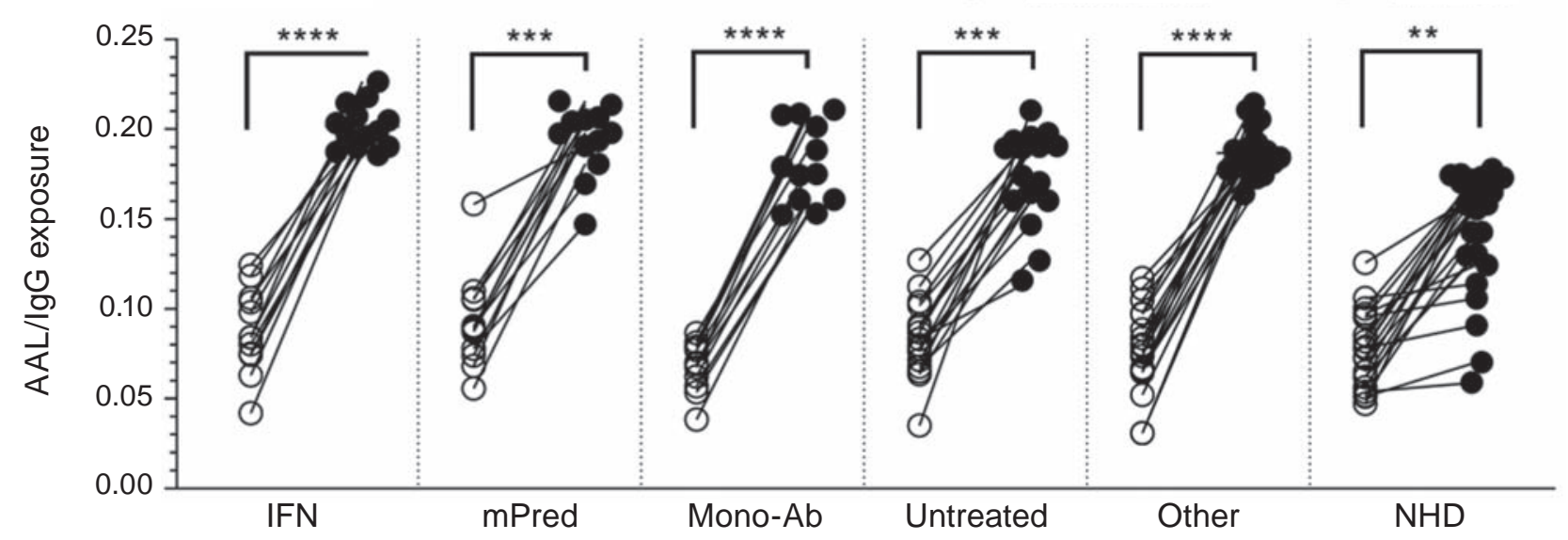

B

Sialic acid exposure

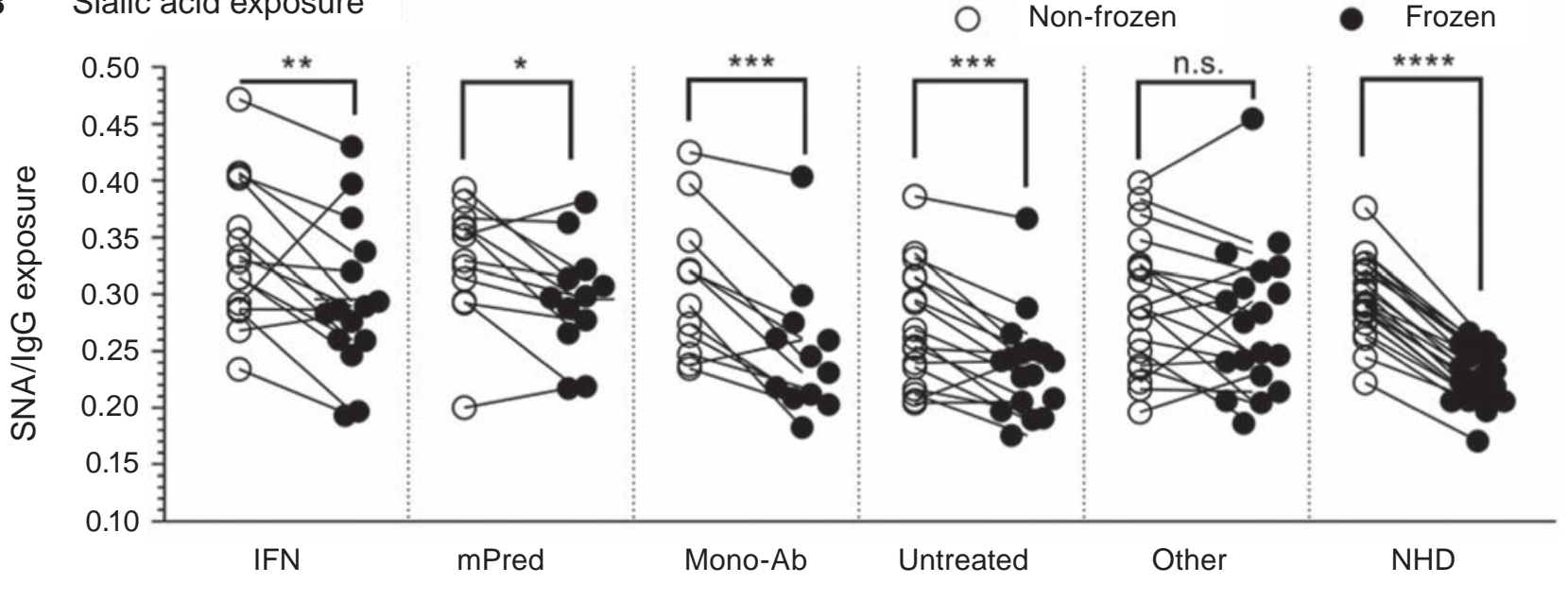

Fig. 4. Freezing conditions increase lectin accessibility to (A) core fucose residues and decrease accessibility to (B) terminal sialic acid residues. Analysis of paired samples of the same sera before (open circles) and after (filled circles) the freezing cycle. Data were corrected for IgG quantities. Statistical data is for the paired Wilcoxon test. ${ }^{*} P<0.05$; ${ }^{* * P}<0.01 ;{ }^{* * *} P<0.001 ;{ }^{* * * * P}<0.0001$; n.s. - not significant. AAL - Aleuria aurantia lectin, IFN - interferon, mPred - methylprednisolone, Mono-Ab-monoclonal antibodies, NHD normal healthy donors, SNA - Sambucus nigra agglutinin

increasing accessibility to the sensing lectin of core fucose residues.

Discrimination of MS patients with the use of native IgG glycan as markers. For both exposure of fucose and sialic acids, we observed changes in glycan exposure on IgG molecules distinguishing NHD and MS patients. Since these changes had different directions (increase of fucose exposure and decrease of sialic acid exposure) in MS compared to NHD, we combined the two parameters for a discriminative plot (Fig. 5, A). In fresh sera, the exposure of Fucose (Fuc) vs sialic acids (S.A.) revealed the population of NHD samples being within a much larger popu- lation of MS patients with no discriminative value (grey circles). However, freezing significantly altered Fuc/S.A. parameters making Fuc/S.A. much stronger for MS patients (black squares) compared to NHD (red circles). As can be seen, changes in Fuc/S.A. exposure were more pronounced for the MS population compared to the NHD population. Visual distinction of this population in Fuc/S.A. exposure coordinates makes the proposed parameters good discriminative markers for MS patients. To calculate the discriminative value of glycan exposure we performed ROC curve analysis for both fucose residues (detected by AAL lectin) and sialic acids (detected by SNA 
A

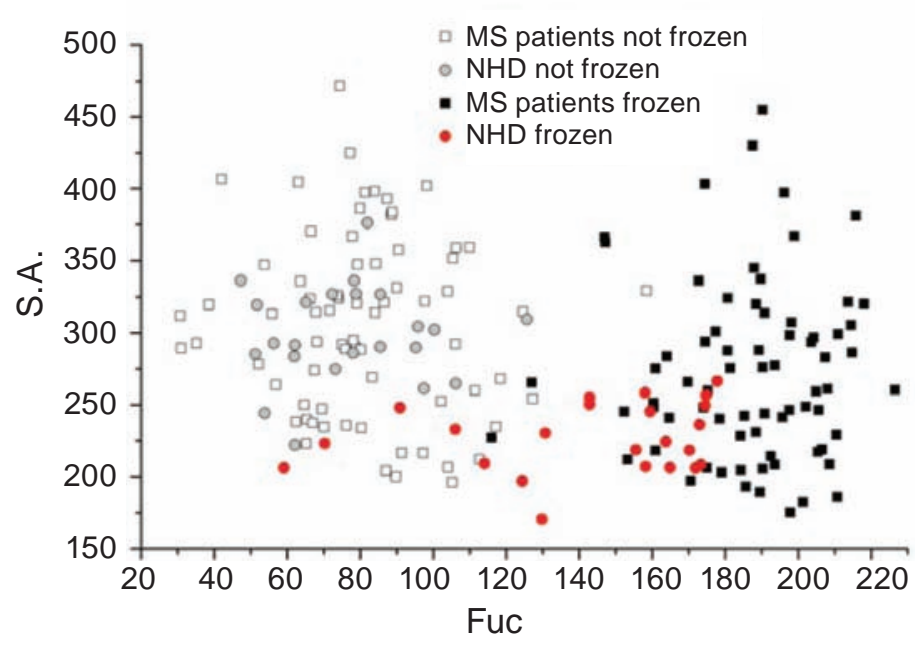

B

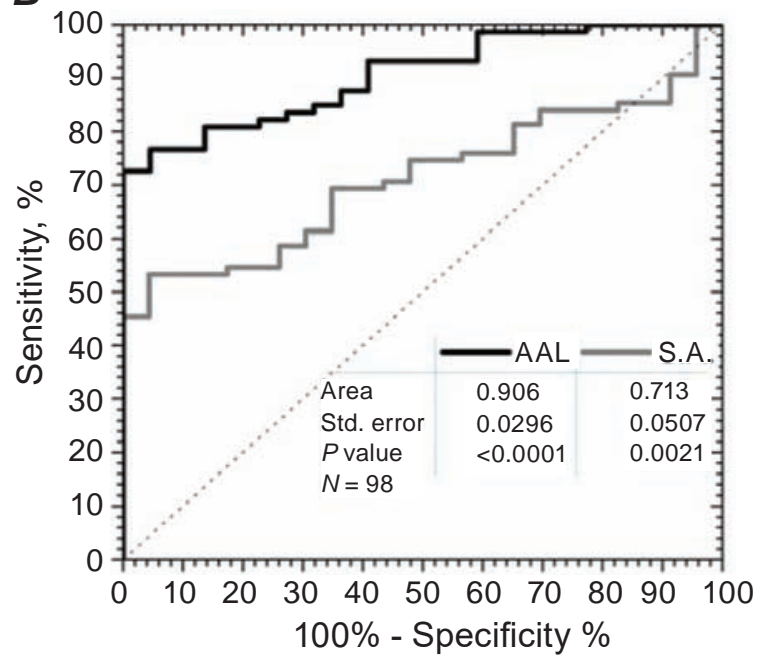

Fig. 5. Diagnostic features of native IgG glycans, if detected with corresponding lectins. (A) Ratio of exposed sialic acids (S.A.) and fucose residues (Fuc) before and after freezing. (B) Receiver operating characteristic (ROC) curves using the lectin-ELISA test as a diagnostic marker of multiple sclerosis (MS). AAL-Aleuria aurantia lectin, NHD - normal healthy donors

analysis). The total number of compared samples was $n=98$ ( 75 MS patients and 23 NHD). For AAL binding the calculated AUROC was $R=0.906$, with a standard error of 0.0296 and $P$-value $<0.0001$, providing a sensitivity of $76.71 \%$ and specificity of $59.03 \%$. For SNA binding, the calculated AUROC was $R=0.713 \pm 0.050, P=0.0021$, providing a sensitivity of $45.33 \%$ and specificity of $90.67 \%$ (Fig. 5, B).

The data indicate that the native glycan conformation of IgG glycans is a good marker of MS. Currently only a few reliable MS markers are available [15]. The marker used most often is oligoclonal IgG bands in cerebrospinal fluid with sensitivity of $>90 \%$, but low specificity of $\sim 35 \%$ and the need for cerebrospinal fluid samples [16,17]. The most reliable serum markers of MS are antibodies to myelin oligodendrocyte glycoprotein (MOG) or myelin basic protein (MBP) that provide specificity and sensitivity in the range of 60 to $85 \%$ [18, 19]. The combination of antibody testing towards MOG, MBP and $\alpha-\beta-$ crystallin, with the diagnostic criteria being the presence of 2 out of 3 parameters, provides a specificity of $80-95 \%$ and sensitivity of $40-60 \%$ [20]. Thus the advantages of proposed test are obvious and currently are being introduced into laboratory diagnostics.

\section{Discussion}

There can be many reasons for an alteration of glycan exposure during freezing, including the ability of IgG to form immune complexes and changes of glycan conformation. Thus, we carefully considered the concentration of total IgG and normalized all data to IgG ELISA values; sera samples were analyzed in pairs to exclude different compositions of glycan moieties due to individual glycan variability. Taking into account the recent data of solution MNR studies described above with terminal sialic acids being quite mobile and tending not to form the "Y" shape projecting outwards from the glycan core, but rather bending in the middle and forming a " $M$ " structure, with the underlying glycans "cowering" with their negative charge and making them sterically inaccessible, we suppose that during freezing ice crystals stabilize the IgG glycan movement. And since crystal formation during freezing favors the most compact glycan arrangements this probably results in the most close location of both branches of $\mathrm{N}$-glycan (Fig. 6). Subsequent defrosting results in a limited range of glycan movement, which in turn leads to: a) inability of a second lectin molecule to bind sialic acid, if one is already bound with a lectin molecule, resulting in decreased sialic acid exposure b) higher core fucose accessibility to small AAL lectin molecules resulting in increased fucose exposure (Fig. 6). Detailed studies of glycan exposure during different freezing conditions are currently underway with the aim to elucidate the molecular details of the phenomena. 


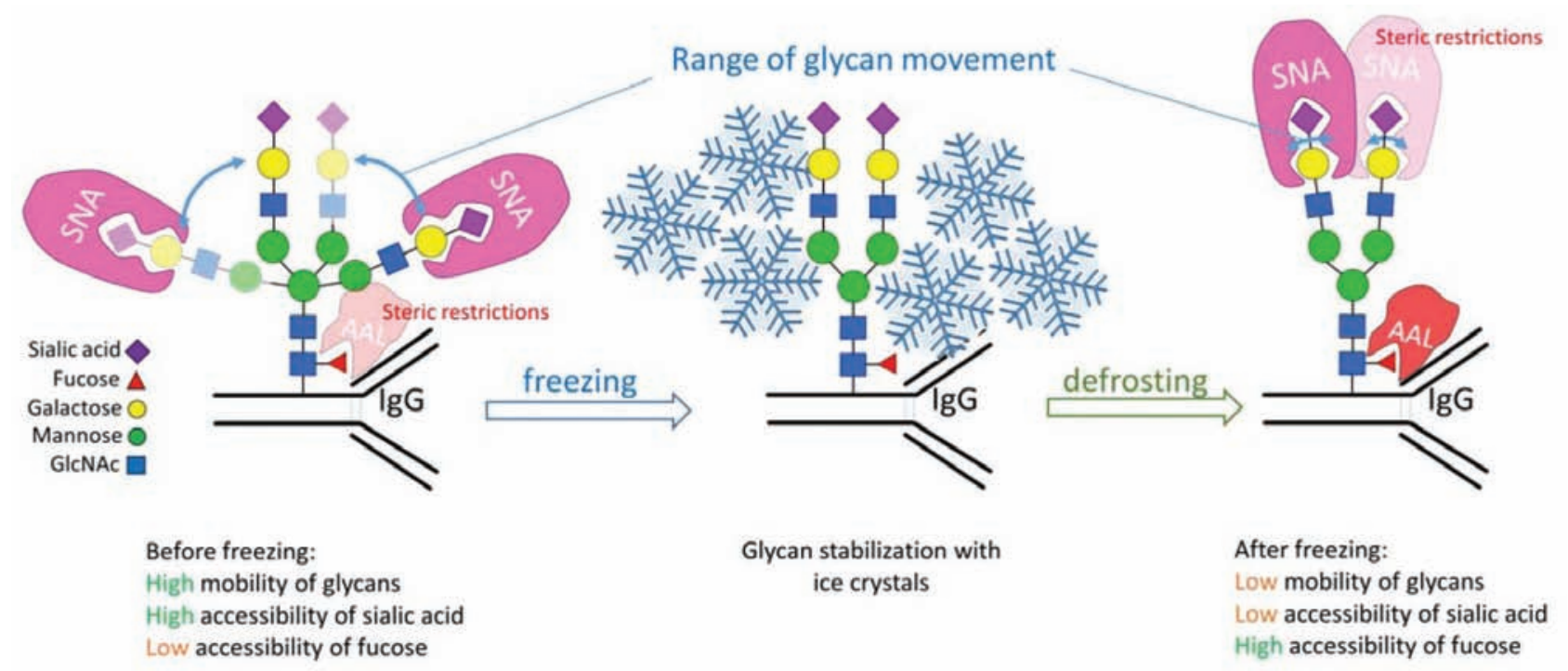

Fig. 6. Scheme illustrating proposed changes in glycan conformations during freezing. AAL-Aleuria aurantia lectin, SNA - Sambucus nigra agglutinin

In summary changes in the internal glycan organization upon freezing lead to a significantly increased exposure of AAL lectin binding targets, as observed in MS patients as compared to NHD. AAL used as a marker for MS discrimination demonstrated an AUROC of $>0.90$, suggesting a very high diagnostic value.

\section{Conclusion}

The IgG glycan marker can be determined in clinically accessible sera samples providing many advantages over markers that require cerebrospinal fluid samples, with comparable diagnostic values. We also demonstrate that freezing, storage and transportation conditions are of great importance when analyzing sera samples, and especially important in multi-center clinical trials and when dealing with native molecule conformation. Thus we propose that for IgG glycan exposure analysis all samples should be stored at $-20^{\circ} \mathrm{C}$ upon collection and then thawed just before the analysis.
Conflict of interest. Authors have completed the Unified Conflicts of Interest form at http://ukrbiochemjournal.org/wp-content/uploads/2018/12/ coi_disclosure.pdf and declare no conflict of interest.

Ethical Committee Approval: Ethics committee of Danylo Halytsky Lviv National Medical University, protocol 20170223/5.

Acknowledgements and financial support. This work was supported by a Grant from the Ministry of Healthcare of Ukraine 0119U101335 and grants from VW Foundation, no 90361 and 97744 . We are thankful to Cedars-Sinai Medical Center's International Research and Innovation in Medicine Program, and the Association for Regional Cooperation in the Fields of Health, Science and Technology (RECOOP HST Association) for their support.

ELISA analysis was performed by T. Dumych as a paid service. 


\section{ВПЛИВ ЗАМОРОЖУВАННЯ НА ЕКСПОНУВАННЯ ГЛІКАНОВИХ МАРКЕРІВ СИРОВАТКОВИХ ІМУНОГЛОБУЛІНІВ IgG ПРИ РОЗСІЯНОМУ СКЛЕРОЗІ}

\author{
М. Боженко1, М. Бойчук ${ }^{1}$, Г. Біла ${ }^{2}$, \\ T. Негрич ${ }^{1 凶}$, Р. Білий
}

${ }^{1}$ Кафедра неврології, Львівський національний медичний університет імені Данила Галицького, Україна;

${ }^{2}$ Кафедра гістології, цитології та ембріології, Львівський національний медичний університет імені Данила Галицького, Україна;

凶e-mail: r.bilyy@gmail.com; tnehrych@gmail.com

Залишки N-гліканів, приєднані до Asn297 молекули імуноглобуліну $\mathrm{IgG}$, відповідають за зміну його структурної конформації і використовуються як маркери багатьох запальних захворювань. Заморожування стабілізує структуру протеїну, тоді як недавні дані ЯМР у розчині виявили сильно змінену рухливість гліканів IgG за різних температур. Метою даної роботи було дослідити, чи впливає заморожування зразків сироваток на експозицію гліканів IgG у хворих на розсіяний склероз (РС) та у здорових донорів (ЗД). Використовували розроблений лектин-імуноензимний аналіз для оцінки експонування нативних гліканів у складі $\operatorname{IgG}$ за допомогою фукозо-специфічного лектину AAL та сіало-специфічного лектину SNA. Зразки сироваток розділяли і негайно заморожували при $-20{ }^{\circ} \mathrm{C}$ або зберігали при $4{ }^{\circ} \mathrm{C}$. Експонування гліканів порівнювали між 5 групами пацієнтів із РC $(n=75)$ проти ЗД $(n=23)$, a також у парних зразках із заморожуванням та без нього. Спостерігали значне збільшення експонування залишків фукози на гліканах імуноглобулінів $\mathrm{IgG}$ у хворих на РС порівняно із ЗД. Це збільшення було лише в тому випадку, якщо сироватки перед аналізом заморожували. Також, експонування сіалової кислоти зменшувалося на зразках РС проти ЗД після заморожування зразків сироваток. Експонування корових залишків фукози та термінальних сіалових залишків суттєво відрізнялися в парних зразках сироваток після заморожування. Комбіновані параметри експонування фукози та сіалової кислоти нативних гліканів у складі імуноглобулінів $\mathrm{IgG}$ із використанням заморожених зразків си- роваток слугували дискримінаційним маркером PC. Для експонування AAL дискримінація групи РС характеризувалась площею під ROC кривою, рівною 0,906 , із чутливістю $76,7 \%$ та специфічністю 59\%, $P<0,0001$.

К л ю ч о в і с л о в а: $\operatorname{IgG}$, глікозилювання, заморожування, запалення, розсіяний склероз.

\section{References}

1. Li T, DiLillo DJ, Bournazos S, Giddens JP, Ravetch JV, Wang LX. Modulating IgG effector function by Fc glycan engineering. Proc Natl Acad Sci USA. 2017; 114(13): 3485-3490.

2. Magorivska I, Döncző B, Dumych T, Karmash A, Boichuk M, Hychka K, Mihalj M, Szabó M, Csánky E, Rech J, Guttman A, Vari SG, Bilyy R. Glycosylation of random IgG distinguishes seropositive and seronegative rheumatoid arthritis. Autoimmunity. 2018; 51(3): 111-117.

3. Knopf J, Magorivska I, Maler JM, Spitzer P, Bilyy R, Biermann MHC, Hychka K, Bondt A, Wuhrer M, Toes REM, Schett G, Herrmann M, Muñoz LE. Low amounts of bisecting glycans characterize cerebrospinal fluid-borne IgG. $J$ Neuroimmunol. 2018; 320: 19-24.

4. Anthony RM, Nimmerjahn F, Ashline DJ, Reinhold VN, Paulson JC, Ravetch JV. Recapitulation of IVIG Anti-Inflammatory Activity With a Recombinant IgG Fc. Science. 2008; 320(5874): 373-376.

5. Biermann MHC, Griffante G, Podolska MJ, Boeltz S, Stürmer J, Muñoz LE, Bilyy R, Herrmann M. Sweet but dangerous - the role of immunoglobulin $G$ glycosylation in autoimmunity and inflammation. Lupus. 2016; 25(8): 934-942.

6. Chen S, Lu C, Gu H, Mehta A, Li J, Romano PB, Horn D, Hooper DC, Bazemore-Walker CR, Block T. Aleuria Aurantia Lectin (AAL)reactive Immunoglobulin G Rapidly Appears in Sera of Animals Following Antigen Exposure. PLoS One. 2012; 7(9): e44422.

7. Stümer J, Biermann MHC, Knopf J, Magorivska I, Kastbom A, Svärd A, Janko C, Bilyy R, Schett G, Sjöwall C, Herrmann M, Muñoz LE. Altered glycan accessibility on native immunoglobulin $\mathrm{G}$ complexes in early rheumatoid arthritis and its changes during therapy. Clin Exp Immunol. 2017; 189(3): 372-382. 
8. Barb AW, Prestegard JH. NMR analysis demonstrates immunoglobulin $\mathrm{G}$ N-glycans are accessible and dynamic. Nat Chem Biol. 2011; 7(3): 147-153.

9. Meier S, Duus J. Carbohydrate dynamics: Antibody glycans wiggle and jiggle. Nat Chem Biol. 2011; 7(3): 131-132.

10. Paryzhak S, Dumych T, Mahorivska I, Boichuk M, Bila G, Peshkova S, Nehrych T, Bilyy R. Neutrophil-released enzymes can influence composition of circulating immune complexes in multiple sclerosis. Autoimmunity. 2018; 51(6): 297-303.

11. Subedi GP, Barb AW. The Structural Role of Antibody N-Glycosylation in Receptor Interactions. Structure. 2015; 23(9): 1573-1583.

12. Polman CH, Reingold SC, Banwell B, Clanet M, Cohen JA, Filippi M, Fujihara K, Havrdova E, Hutchinson M, Kappos L, Lublin FD, Montalban X, O'Connor P, SandbergWollheim M, Thompson AJ, Waubant E, Weinshenker B, Wolinsky JS. Diagnostic criteria for multiple sclerosis: 2010 revisions to the McDonald criteria. Ann Neurol. 2011; 69(2): 292-302.

13. Kurtzke JF. Rating neurologic impairment in multiple sclerosis: an expanded disability status scale (EDSS). Neurology. 1983; 33(11): 14441452.

14. Magorivska I, Muñoz LE, Janko C, Dumych T, Rech J, Schett G, Nimmerjahn F, Bilyy R,
Herrmann M. Sialylation of anti-histone immunoglobulin $G$ autoantibodies determines their capabilities to participate in the clearance of late apoptotic cells. Clin Exp Immunol. 2016; 184(1): 110-117.

15. Housley WJ, Pitt D, Hafler DA. Biomarkers in multiple sclerosis. Clin Immunol. 2015; 161(1): 51-58.

16. Katsavos S, Anagnostouli M. Biomarkers in Multiple Sclerosis: An Up-to-Date Overview. Mult Scler Int. 2013; 2013: 1-20.

17. Gajofatto A, Calabrese M, Benedetti MD, Monaco S. Clinical, MRI, and CSF Markers of Disability Progression in Multiple Sclerosis. Dis Markers. 2013; 35(6): 687-699.

18. Tian Z, Zhao X, Li Z, Zhang F, Cao F, Li S, Shao M, Dong Y. Evaluation of myelin basic protein levels with receiver operating characteristic curves for diagnosis of multiple sclerosis. Nan Fang Yi Ke Da Xue Xue Bao. 2009; 29(2): 250-252.

19. Di Pauli F, Reindl M, Berger T. Biological Markers of Prognostic Value in Multiple Sclerosis. Eur Neurol Rev. 2008; 3(2): 94.

20. Vojdani A, Vojdani E, Cooper E. Antibodies to myelin basic protein, myelin oligodendrocytes peptides, alpha-beta-crystallin, lymphocyte activation and cytokine production in patients with multiple sclerosis. J Intern Med. 2003; 254(4): 363-374. 